Majid Dashti Barmaki, Mohsen Rezaei, Ezzat Raeisi, and Javad Ashjari. Comparison of surface and interior karst development in Zagros Karst Aquifers, Southwest Iran. Journal of Cave and Karst Studies, v. 81, no. 2, p. 84-97. DOI:10.4311/2017ES0120

\title{
COMPARISON OF SURFACE AND INTERIOR KARST DEVELOPMENT IN ZAGROS KARST AQUIFERS, SOUTHWEST IRAN
}

\author{
Majid Dashti Barmaki', Mohsen Rezaei², c, Ezzat Raeisi ${ }^{3}$, and Javad Ashjari ${ }^{4}$
}

\begin{abstract}
Aggressive recharge water is capable of widening the surface and interior openings of karstic layers that leads to the easy flowing of water in this type of aquifers. The object of this study is to understand if surface karstification is the same as the interior karst development of an aquifer. Surface karstification was analyzed using Geographic Information System and remote sensing techniques, while interior karstification was studied with spring hydrograph analysis. The study area includes seven carbonate aquifers in the Zagros Region of Iran. The surface karstification of these aquifers is controlled by different factors including the thickness of carbonate formations, distance from faults, fracture density, precipitation, temperature, vegetation index, slope, and relief. The most important factors are precipitation and presence and density of faults and fractures; while the least significant factor is the vegetation cover. The spring hydrograph analysis shows that there are different ways of estimating the relative karst development, but each parameter that impacts the specific character of the karst aquifer might be independent of others. Furthermore, comparing the relative surface and interior karst development demonstrates that the possible relationship between them is unpredictable. Consequently, we define a specific and unique numeric method to assess the interior karst development that permits a meaningful concept and comparison among different aquifers throughout the world.
\end{abstract}

\section{Introduction}

The progression of the dissolution and development of karst in carbonate formations usually results in increased complexity in the structure and hydrogeologic properties of the karstic aquifer. The degree of karst development in these aquifers is influenced by various factors. Lithology, carbonate rocks thickness, tectonic setting (e.g., fractures and faults), relief, temperature, type and amount of precipitation, and partial pressure of $\mathrm{CO}_{2}$ are the most important factors determining the degree of karst development (White, 1988). Moreover, the vegetation type and intensity, and the thickness of the soil layer also play a meaningful role in karstification (Barany Kevei, 2007).

Carbonate pure lithology is more suitable for karst development, as the presence of impurities such as marl and silica minerals may impede the dissolution progress. The thickness of soluble rock layers and the stratigraphic position of them among the non-soluble layers control the extent of karst development. In the case of thin soluble rocks sandwiched between non-soluble layers, it is less likely that karstification occurs (Seif and Ebrahimi, 2014). Furthermore, the impermeable and non-soluble thin layers of rocks as interfering layers in the carbonate layers impede the water movement into the deeper parts, and hence, the dissolution only occurs in the top carbonate sequences (Lowe, 1992; Shabab-Brojeni, 2011).

Faults and fractures represent the effects of the tectonic setting. Most fractures are caused by the tectonic forces, weathering, and mechanical breakdown. Relief and local base level are the main geomorphologic factors that control the regional groundwater flow in karstic aquifers. They define boundary conditions and control the recharge and discharge locations of the aquifer (White, 1988; Palmer, 2000). The location of local base level is inherited from historical and regional tectonic processes. Temperature and precipitation, which determine the availability of water, are certainly the principal variables controlling total denudation of the rocks by dissolution (Ford and Williams, 2007). The climate variability in regional and global scale results in the various spatial distribution of precipitation, temperature, and evapotranspiration, and consequently, significant changes in vegetation cover (Ekmekci and Tezcan, 2011). The type and density of vegetation cover of karst terrains are variable. Due to the activity of soil microbes, the vegetation cover usually improves the water aggressiveness by increasing the $\mathrm{P}_{\mathrm{CO} 2}$. Furthermore, the presence of vegetation regulates dissolution over a vast area. The slope controls water recharge into the subsurface. The residence time of surface runoff in gentle dips is considerably more than in steep dips, so the rate of infiltration in the gentle dips can be more than the steep dips.

These parameters must be active together to increase the karstification and enhancement of one of them imposes positive feedback to the others, though their weighted effects on dissolution vary.

\footnotetext{
${ }^{1}$ Faculty of Earth Sciences, Kharazmi University of Tehran, Iran

2 Department of Earth Sciences, Shiraz University, Shiraz, Iran.

${ }^{3}$ Department of Earth Sciences, College of Science, Shiraz University, Shiraz, Iran

${ }^{4}$ Abanrood Tadbir Engineering Company, Tehran, Iran

c Corresponding author: mohsen-rezaei@shirazu.ac.ir
} 
The Zagros Mountains Ranges are crucial sources of surface water and groundwater of Iran, which outcrop more than $100,000 \mathrm{~km}^{2}$ of carbonate formations (Raeisi, 2002). The groundwater of carbonate aquifers emerge at springs, discharge to the adjacent alluvial aquifer, or pour into traversing rivers (Ashjari and Raeisi, 2006). The Asmari Formation, with lithology of limestone and dolomite, is the most important groundwater and oil reservoir in this region. Aquifers formed in the Asmari Formation have different hydraulic behavior.

A lot of research has been developed to understand the hydrogeologic characteristics of Zagros Karst aquifers, including from Dashti et al. (2015), Ashjari (2007), Raeisi and Stevanovic (2010), Karimi et al. (2005 and 2016), Chitsazan et al. (2015), and Kalantri et al. (2010). The main object of this research is to investigate the causes of the diversity in surface and interior karstification. Furthermore, springs responses to external stresses are investigated. The combined methods of GIS and spring hydrograph analyses in seven selected karstic springs are used to achieve these goals.

\section{Study Area}

The Zagros Mountains extend from the south of Turkey and north and northeast of Iraq to the south of Iran. The carbonate formations including limestone, dolomite, and dolomitic-limestone, form the high mountains and mainly expose as sequential anticlines and synclines (Alavi, 2004). Foldings cause superimposing of some of these carbonate formations, mostly near to the main thrust fault, with very steep dips of the layers. Gentler dips and broader spacing among the folds peak by distancing from the frequency of faults allow for the deposition of recent sediments as alluvium. The selected anticlines lie in the central segment of the Zagros in Iran (Fig 1). The rivers traverse these folds from the limbs or the plunges. In this research, five anticlines including Anar, Dashtak, Pabdeh, Rig, and Delisib have been studied. The locations of these anticlines are presented in Figure 1.

The fold axes of selected anticlines trend from the northwest to the southeast parallel to the main Zagros thrust fault. The lithology and the exposed formations of these anticlines are summarized in Table 1 in chronologic order from the youngest to oldest according to Stöcklin (1968 and 1974). Surface geology and cross sections of these five anticlines are shown in Figures 2 to 5.

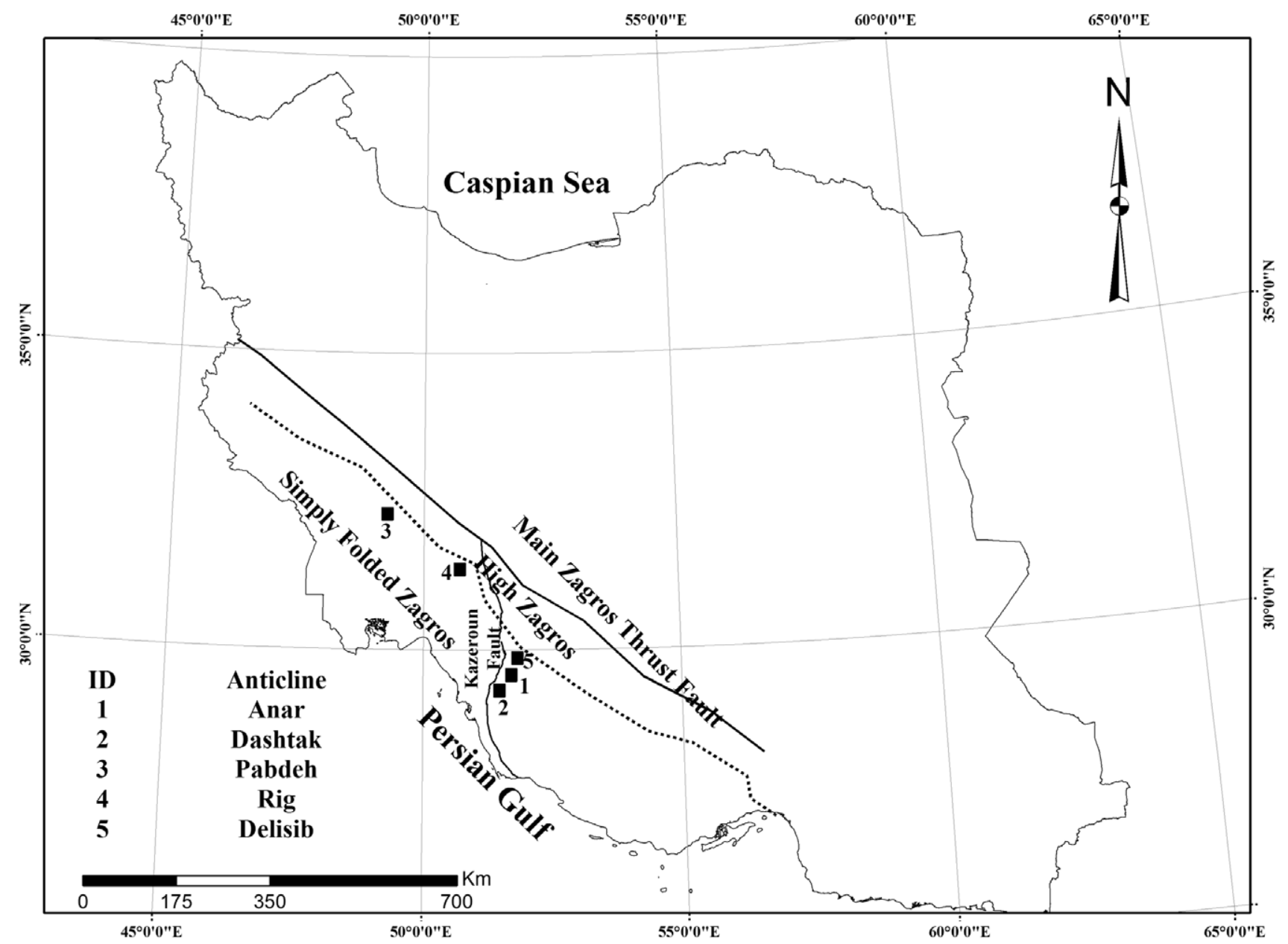

Figure 1. The study areas include location of Anar, Dashtak, Pabdeh, Rig, and Delisib anticlines. 
Table 1. The lithologic characteristics of the exposed formations at anticlines (Aghanabati, 2004; Alavi, 2004).

\begin{tabular}{|c|c|c|c|c|c|}
\hline Anticlines & Formation name & Abbreviation & Age & Lithology & Thickness \\
\hline \multirow[t]{3}{*}{ Anar } & Gachsaran & Gs & Miocene & salt, anhydrite, colorful marls & $>1000$ \\
\hline & Asmari-Jahrum & As-Ja & Paleocene-Miocene & limestone, anhydrite, and dolomite & 300 \\
\hline & Pabdeh-Gurpi & $\mathrm{Pd}-\mathrm{Gu}$ & upper Cretaceous- Eocene & $\begin{array}{c}\text { marl, Shale, mudstone, and layers of } \\
\text { limestone with thin clay }\end{array}$ & 650 \\
\hline \multirow[t]{5}{*}{ Dashtak } & Bakhtiari & $\mathrm{Bk}$ & Pleistocene & conglomerate & $<200$ \\
\hline & Gachsaran & Gs & Miocene & salt, anhydrite, colorful marls & $>1000$ \\
\hline & Asmari-Jahrum & As-Ja & Paleocene-Miocene & limestone, anhydrite, and dolomite & 350 \\
\hline & Pabdeh-Gurpi & $\mathrm{Pd}-\mathrm{Gu}$ & upper Cretaceous- Eocene & $\begin{array}{l}\text { marl, Shale, mudstone, and layers of } \\
\text { limestone with thin clay }\end{array}$ & 650 \\
\hline & Ilam-Sarvak & II-Sv & upper Cretaceous & limestone & 450 \\
\hline \multirow[t]{4}{*}{ Pabdeh } & Aghajari & $\mathrm{Aj}$ & upper Neogene & sandstone & 150 \\
\hline & Mishan & $\mathrm{Mn}$ & lower Neogene & shale, limestone, and layers of dolomite & 100 \\
\hline & Asmari & As & Oligocene-Miocene & limestone, anhydrite & 300 \\
\hline & Pabdeh & $\mathrm{Pd}$ & Paleocene-Eocene & $\begin{array}{c}\text { marl, Shale, and layers of limestone with } \\
\text { thin clay }\end{array}$ & 400 \\
\hline \multirow[t]{4}{*}{ Rig } & Bakhtiari & $\mathrm{Bk}$ & Pleistocene & conglomerate & 100 \\
\hline & Gachsaran & Gs & Miocene & salt, anhydrite, colorful marls & 300 \\
\hline & Asmari & As & Oligocene-Miocene & limestone, anhydrite, and dolomite & 364 \\
\hline & Pabdeh & $\mathrm{Pd}$ & Paleocene -Eocene & $\begin{array}{c}\text { marl, Shale, and layers of limestone with } \\
\text { thin clay }\end{array}$ & 700 \\
\hline \multirow[t]{5}{*}{ Delisib } & Bakhtiari & $\mathrm{Bk}$ & Pleistocene & conglomerate & 100 \\
\hline & Razak & $\mathrm{Rz}$ & Miocene & shale and layers of limestone & 200 \\
\hline & Asmari-Jahrum & As-Ja & Paleocene-Miocene & limestone, anhydrite, and dolomite & 480 \\
\hline & Pabdeh-Gurpi & $\mathrm{Pd}-\mathrm{Gu}$ & upper Cretaceous- Eocene & $\begin{array}{l}\text { marl, Shale, mudstone, and layers of } \\
\text { limestone with thin clay }\end{array}$ & 650 \\
\hline & Bakhtiari & $\mathrm{Bk}$ & Pleistocene & conglomerate & 100 \\
\hline
\end{tabular}

Asmari and Sarvak are the most important karst formations and constitute the largest karst aquifers and reservoirs with many spring discharges. In our research, information has been collected from seven important karst springs including Bavan $\left(\mathrm{Sp}_{1}\right)$, Sarabroud $\left(\mathrm{Sp}_{2}\right)$, Sasan $\left(\mathrm{Sp}_{4}\right)$, Bibitalkhun $\left(\mathrm{Sp}_{7}\right)$, Atashgah $\left(\mathrm{Sp}_{11}\right)$, Kharandaz $\left(\mathrm{Sp}_{19}\right)$, and Abshar $\left(\mathrm{Sp}_{21}\right)$. The characteristics of these springs are presented in Table 2, and their locations are depicted in Figures 2 to 5. The resurgences of these springs and the main part of each catchment area are located in the Asmari Formation.

Bavan $\left(\mathrm{Sp}_{1}\right)$ and Sarabroud $\left(\mathrm{Sp}_{2}\right)$ springs are two important springs of the Anar anticline (Fig 2). The core of this anticline is formed by the Sarvak Formation, which lies under the impermeable layers of the Pabdeh-Gurpi Formations. The Asmari-Jahrum Formations cover the latter formation in the Zagros, but it has been eroded by the active tectonics in the middle sections of the anticline and near to the peak. As a result, the Asmari-Jahrum formations are disconnected into two distinct parts; north and south limbs. Spring $\mathrm{Sp}_{1}$ emerges from the northern sector of the Asmari Formation while the $\mathrm{Sp}_{2}$ discharges the southern sector. Several faults, mainly in the perpendicular or oblique direction to the fold axis, cross the anticline. The solution features of dry valleys, karren, grike, rain pits, solution pans, and polje are observed. Dasht-e-Arzhan polje is formed at the southeast end of the anticline as a result of interactions of two normal faults and consequently the formation of a wide depression (Jamali et al., 2015). The Fahlian River is parallel to anticline elongation and turns in response to the plunge of the anticline from the northwest plunge and continues its flow to the south of the region.

Sasan Spring $\left(\mathrm{Sp}_{4}\right)$ (Fig. 2) is the most important spring for the Dashtak anticline. There are several other small springs adjacent to Sasan Spring. The anticline is composed of Asmari-Jahrum Formations. Since the Shapor River traverses and erodes the anticline near to the northwest plunge, the Pabdeh-Gurpi, as the bedrock of the aquifer, is 


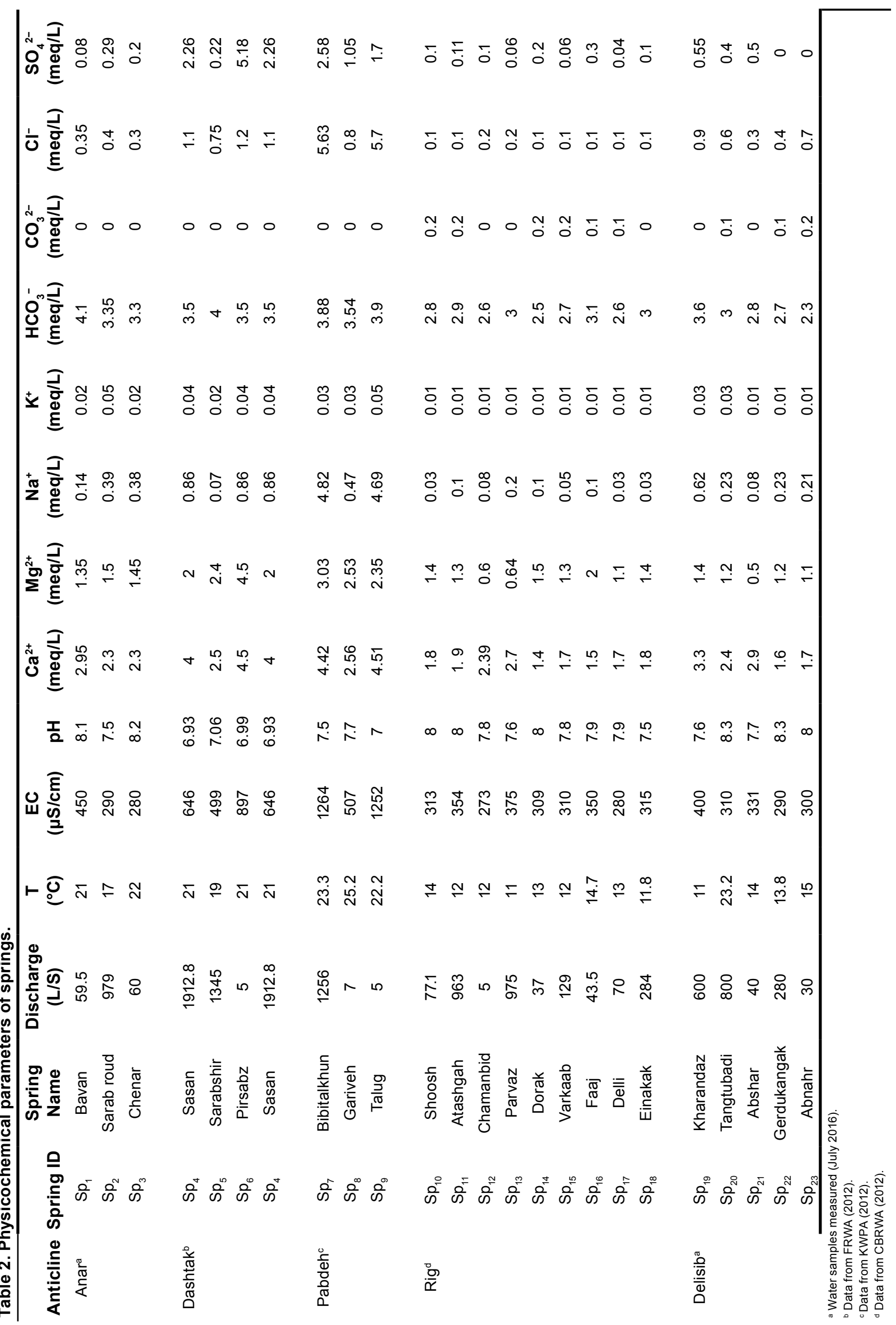




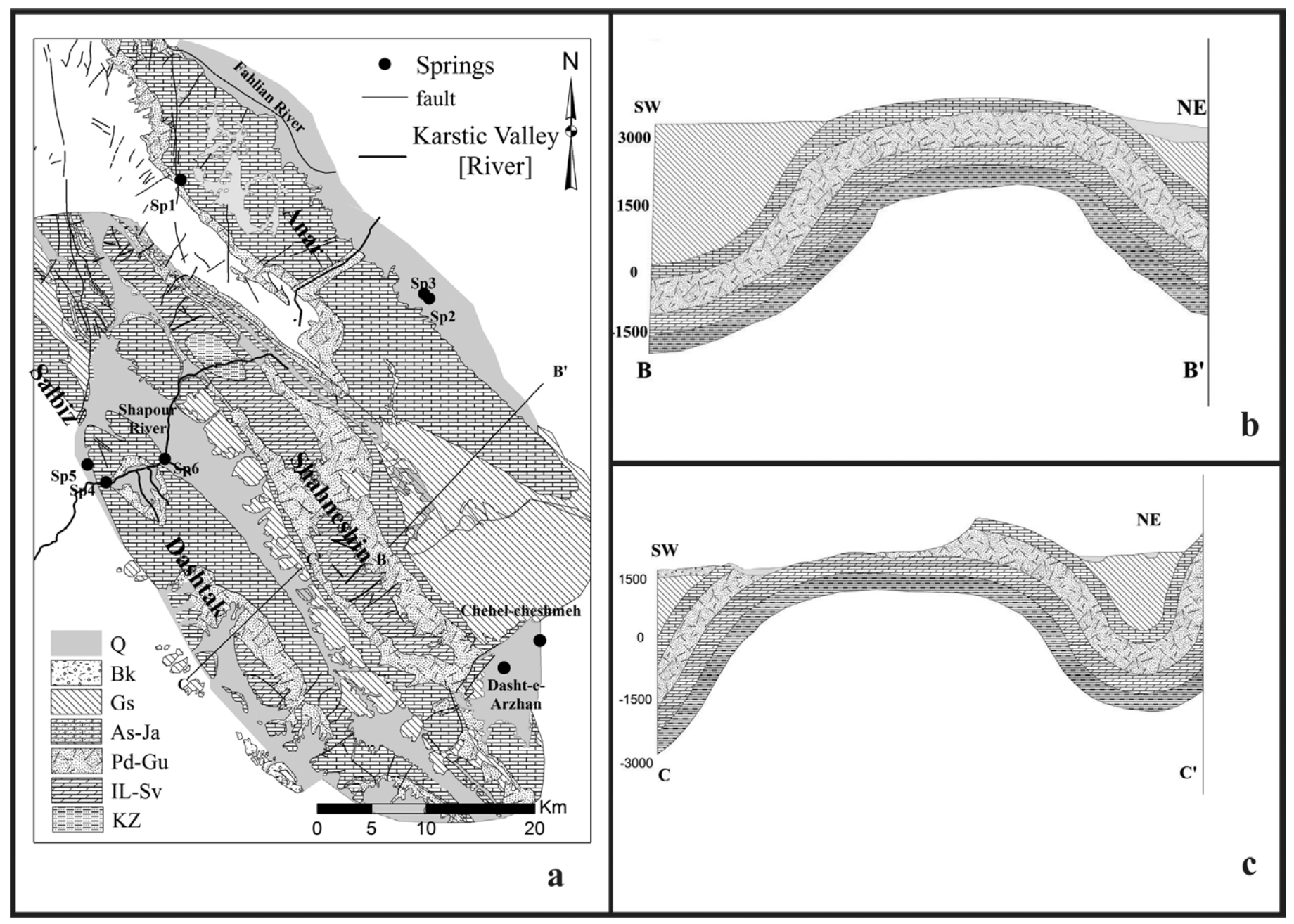

Figure 2. A) Geologic map of Anar and Dashtak anticlines, B) Cross section of Anar anticline, C) Cross section of Dashtak anticline.

exposed. The impermeable layer of the Gachsaran Formation lies on top of the Asmari-Jahrum and may be outcropped clearly or hidden by a thin layer of alluvium. The regional fault of Qatar-Kazerun passes from the northwest plunge and continues to the south in the Kazerun plain. The branches of this fault are crushed severely in the west part of the anticline, which leads to the formation of several small compartments of the carbonate aquifers. The main karst features are caves, especially prominent is the cave of Shapour (Raeisi and Kowsar, 1997).

The Pabdeh anticline, Bibitalkhun Spring $\left(\mathrm{Sp}_{7}\right)$ emerges from the Asmari-Jahrum Formations of the southern limb of the anticline (Fig 3). The geologic settings of the layers are fairly similar to the Anar anticline. The Asmari-Jahrum Formations are separated into two parts in the limbs with the Pabdeh Formation exposed in the core. Moreover, the Gachsaran Formation overlays the Asmari-Jahrum in the base of the anticline. A thrust fault passes from the southern limb in the same direction of the fold that causes the high depression of the southern plain. Dolines are observed along a strike-slip fault near the southern plunge. The Talug River passes through the anticline and cuts into the carbonate formation.

Atashgah Spring $\left(\mathrm{Sp}_{11}\right)$ appears on the southern limb of the Rig anticline (Fig 4). The Pabdeh Formation outcrops in the core and disconnects the Asmari-Jahrum Formations of the limbs. The impervious formation of Gachsaran is adjacent to the northern limb while the alluvium is deposited beside the southern limb. Since the anticline lies very close to the main thrust fault of the Zagros, the rocks are intensively fractured and faulted. Neither doline nor polje are observed. The Khersan River passes near to the southern plunge and then turns to the northwest, parallel to the anticline elongation. Few springs emerge from the southern limb and discharge water to the river.

The Delisib anticline is the source of the Kharandaz and Abshar Springs $\left(\mathrm{Sp}_{19}\right.$ and $\left.\mathrm{Sp}_{21}\right)$ (Fig 5). The core of the anticline is a thick layer of the Pabdeh-Gurpi. The Razak Formation lies on top of the carbonate rocks of Asmari-Jahrum Formations. This Formation is hidden under thin alluvium at some areas. The solution features of dry valleys, karren, grike, rain pits, solution pans, and polje are observed. 


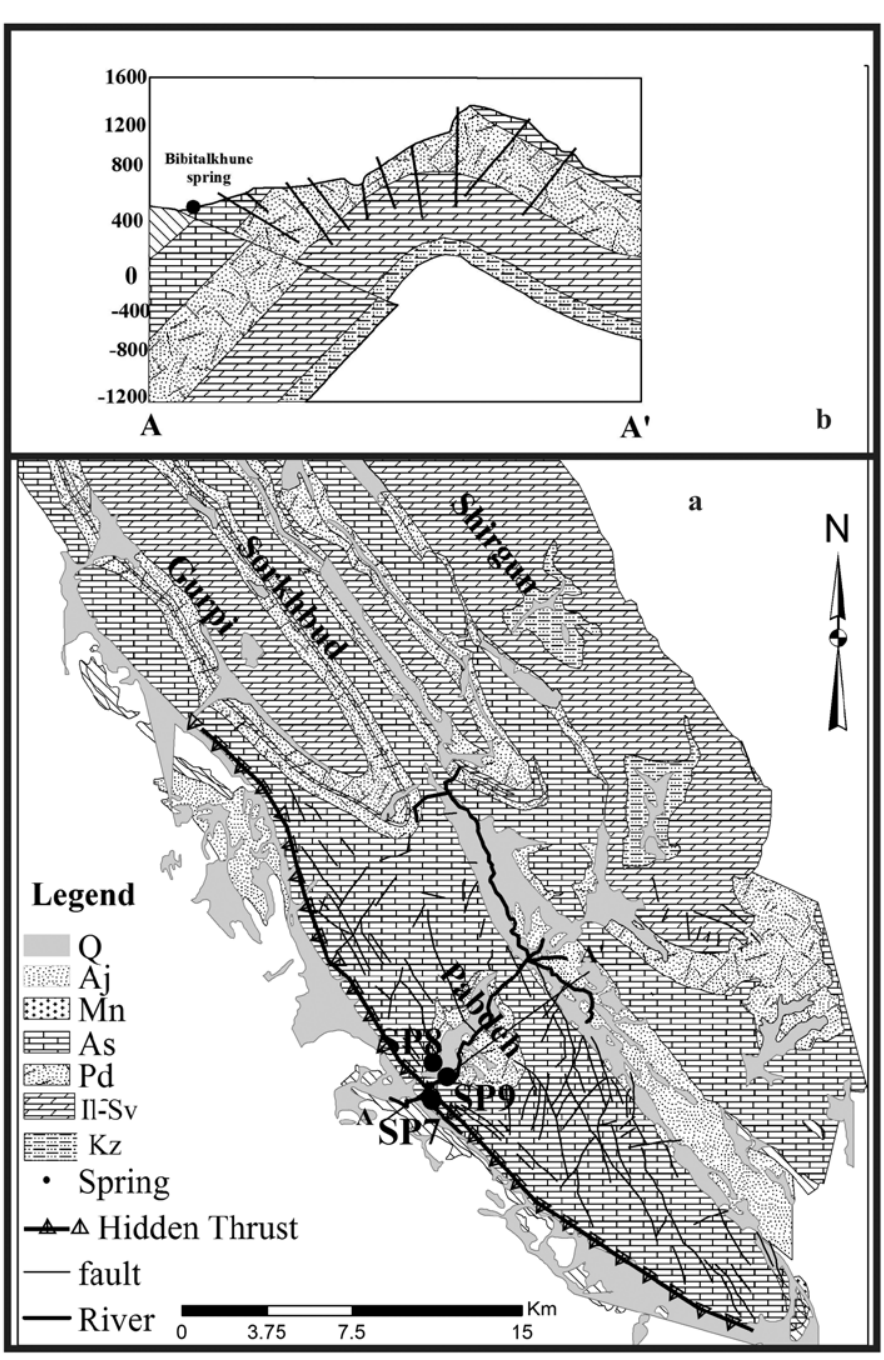

Figure 3. A) Geologic map of Pabdeh anticlines, B) Cross section of Pabdeh anticline.

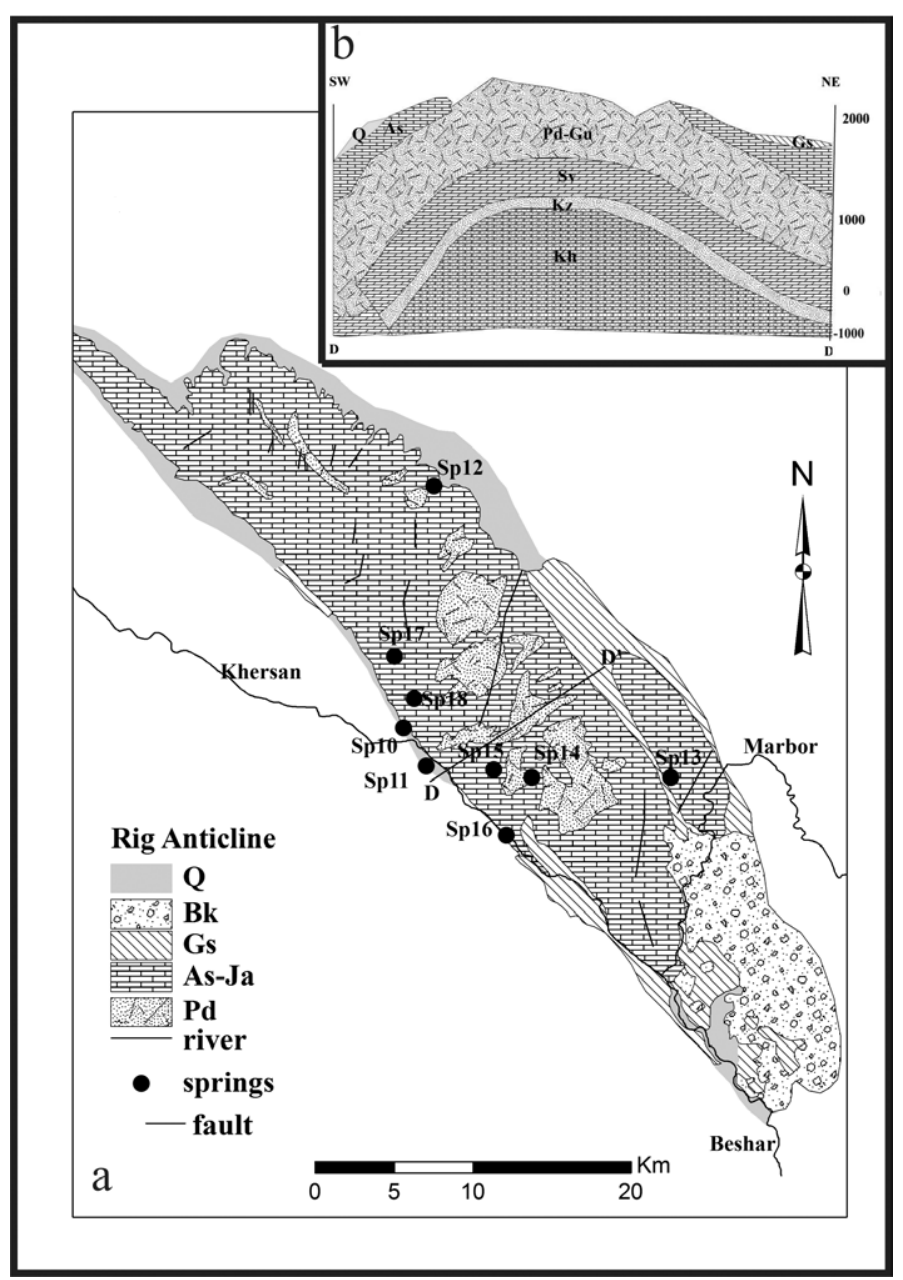

Figure 4. A) Geologic map of Rig anticlines, B) Cross section of Rig anticline.

\section{Material and Methods}

The geologic maps of the study areas were prepared based on geologic maps of $1 / 100,000$ and $1 / 250,000$ from the Iranian Oil Operating Company of Iran. Physicochemical parameters of springs (Table 2), and rainfall data were collected from the Fars Regional Water Authority (FRWA, 2012), the Chaharmahal and Bakhtiari Water Authority (CBRWA, 2012), and the Khuzestan Water and Power Authority (KWPA, 2012). The field study and water sampling of groundwater resources were conducted if there were not enough data from previous studies.

In our study, GIS and remote sensing techniques were used to evaluate surface karstification. Thickness of carbonate formations (Th), tectonic setting (distance from faults (FB) and fracture density (FD)), climate (precipitation (P) and temperature $(T)$ ), vegetation index $(\mathrm{V})$, slope $(\mathrm{S})$, and relief $(\mathrm{R})$ were applied as interpretation elements to extract the thematic layers.

The karstic layers are carbonate formations of Sarvak and Asmari Formations that give the highest karst potential scores. The stratigraphic thickness of these rocks had an important effect on karst development. Precipitation, determining the availability of water for chemical reactions, and temperature, determining the speed of chemical reaction, are essential factors in dissolution. The impact of changes in the elevation can be checked as climate factors; the value and type of precipitation, as well as values of temperature. For this reason, the elevation was not mentioned as an independent factor. Accordingly, the correlation charts of (precipitation-altitude) and (temperature-altitude) were plotted. By using extrapolating from the different stations, a linear equation was fitted to the available data. Vegetation is found to have an important role in karst development through absorption of calcium and magnesium by roots and production of 


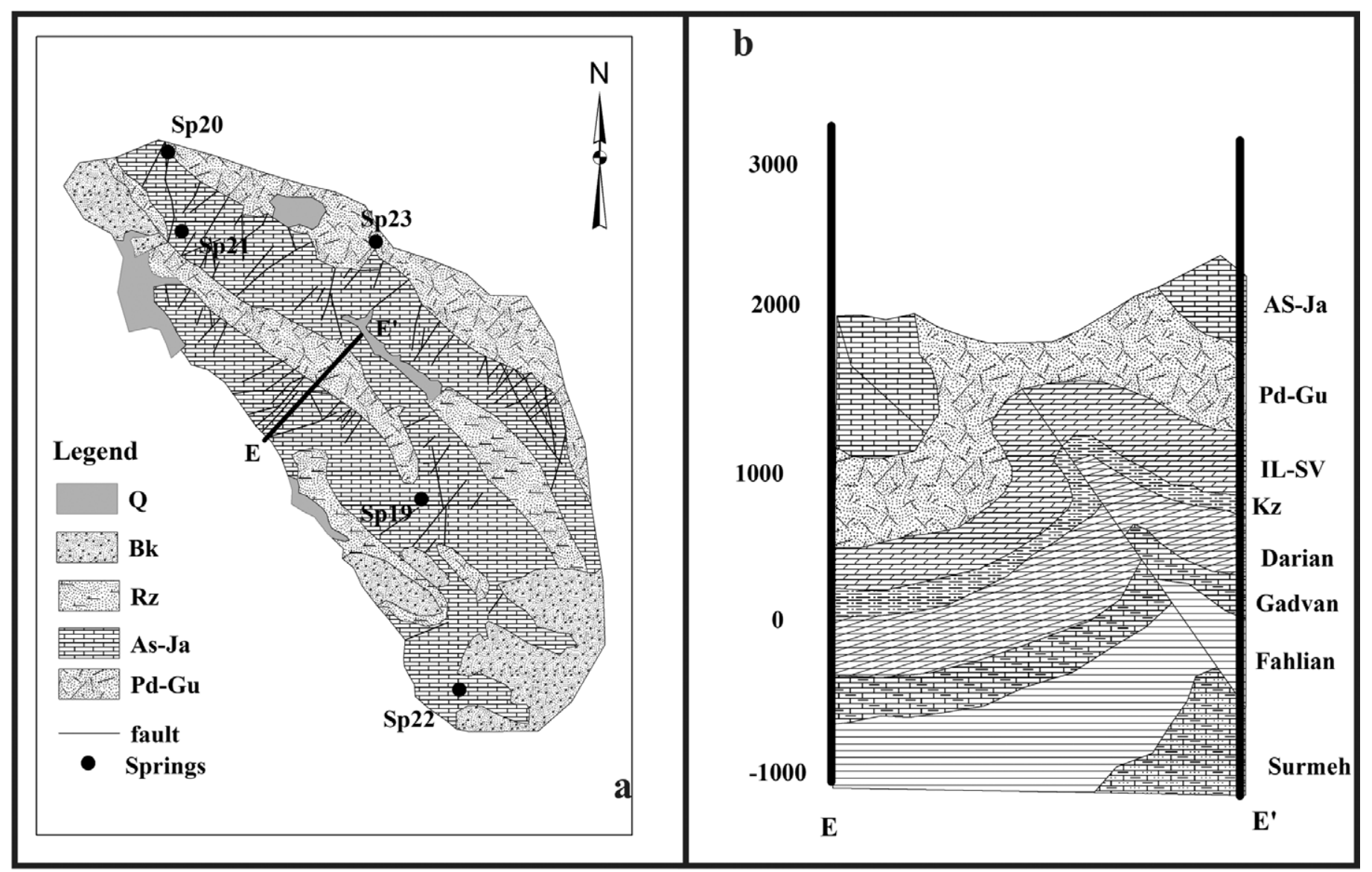

Figure 5. A) Geologic map of Delisib anticlines, B) Cross section of Delisib anticline.

carbon dioxide (Ford and Williams, 2007). Soil Adjusted Vegetation Index (SAVI) was used in areas with low vegetative cover (i.e., < 40 \%) (Huete, 1988; Panda et al., 2010). The SAVI was used for detection of natural vegetation cover change in this study because of its acceptable accuracy and ability to detect the vegetation at study areas. The slope map, calculated based on percentage, was derived from a digital elevation model (DEM). Relief is the last factor affecting karst development. This parameter is the controlling factor of flow direction at carbonate anticlines. As mentioned previously, the link between aquifer discharge locations and major flow direction indicates the local base level at study areas. First, the water flow direction at each of the anticlines should be defined. The local base level of karst areas was the lowest point to which water can flow, such as karst valley rivers or springs. Therefore, the local base level should be defined to obtain the relief factor at each anticline based on assigned local base levels.

Each factor was provided as a separate layer in GIS to determine karst development at study areas. GDEM of Iran (DEM, Iran SRTM - Shuttle Radar Topography Mission Dem data available at 3 arc second, ca. 90 m), geologic maps $(1 / 100,000,1 / 250,000)$, Landsat ETM 8 images, as well as hydrologic and groundwater data of study areas were used. GIS (ArcGIS 10) and remote sensing (PCI Geomatica) software packages were applied in data management and processing. All data were converted to digital format. Then, different layers were created and integrated in GIS. These steps, then followed by analysis and interpretation of the results. To determine which factors affect karst development and to what degree, experts were consulted to provide judgments on the importance of criteria (Table 3). Weighting of the maps was performed by using an Analytical Hierarchical Process (AHP). AHP, as a multi-objective and multi-criteria decision-making approach, was developed by Saaty (1980). It was based on a pair-wise criteria comparison that has been extensively studied and refined. This approach enables the user to achieve a scale of preference drawn from a set of alternatives. Maps were combined applying the weighted index overlay in GIS that is a technique for applying a common measurement scale of values to diverse and dissimilar inputs to create an integrated analysis.

The recharge of the study areas is mainly in the form of direct precipitation, rarely as snow, and in some cases, as seepage from rivers traversing the anticlines. The average precipitation over anticline sub-basin surfaces was estimated by using the precipitation-altitude relation and the DEM. Since it is the basis for all hydrologic analysis, the next 
Table 3. Factors affecting the karst development, and the assigned weights and

ranks for aquifers.

\begin{tabular}{|c|c|c|c|}
\hline Factor & Range & $\mathbf{R}^{\mathbf{a}}$ & $\mathbf{W}^{\mathbf{b}}$ \\
\hline \multirow{5}{*}{$\begin{array}{c}\text { Thickness of Carbonate Formations, } \\
\text { Th }(\mathrm{m})\end{array}$} & $<300$ & 1 & 0.14 \\
\hline & $>300$ and $<350$ & 2 & 0.14 \\
\hline & $>350$ and $<400$ & 3 & 0.14 \\
\hline & $>400$ and $<450$ & 5 & 0.14 \\
\hline & $>450$ & 8 & 0.14 \\
\hline \multirow[t]{6}{*}{ Precipitation, $\mathrm{P}$ (mm/y) } & $<500$ & 1 & 0.13 \\
\hline & $500-600$ & 2 & 0.13 \\
\hline & $600-700$ & 3 & 0.13 \\
\hline & $700-800$ & 5 & 0.13 \\
\hline & $800-900$ & 7 & 0.13 \\
\hline & $>900$ & 9 & 0.13 \\
\hline \multirow[t]{8}{*}{ Distance from Faults, FB (m) } & $<100$ & 9 & 0.23 \\
\hline & $100-200$ & 8 & 0.23 \\
\hline & $200-350$ & 7 & 0.23 \\
\hline & $350-500$ & 6 & 0.23 \\
\hline & $500-650$ & 5 & 0.23 \\
\hline & $650-800$ & 4 & 0.23 \\
\hline & $800-1000$ & 3 & 0.23 \\
\hline & $>1000$ & 1 & 0.23 \\
\hline \multirow[t]{4}{*}{ Fracture Density, FD (\%) } & $<25$ & 2 & 0.19 \\
\hline & $25-50$ & 5 & 0.19 \\
\hline & $50-75$ & 7 & 0.19 \\
\hline & $>75$ & 9 & 0.19 \\
\hline \multirow[t]{4}{*}{ Temperature, $\mathrm{T}\left({ }^{\circ} \mathrm{C}\right)$} & $<10$ & 8 & 0.05 \\
\hline & $10-15$ & 6 & 0.05 \\
\hline & $15-20$ & 4 & 0.05 \\
\hline & $>20$ & 2 & 0.05 \\
\hline \multirow{4}{*}{$\begin{array}{l}\text { Soil Adjusted Vegetation Index, SAVI } \\
\qquad(\%)\end{array}$} & No Vegetation & 0 & 0.09 \\
\hline & Low Vegetation & 2 & 0.09 \\
\hline & $\begin{array}{l}\text { Medium } \\
\text { Vegetation }\end{array}$ & 5 & 0.09 \\
\hline & High Vegetation & 8 & 0.09 \\
\hline \multirow[t]{5}{*}{ Slope, S (\%) } & $<20$ & 9 & 0.05 \\
\hline & $20-40$ & 7 & 0.05 \\
\hline & $40-60$ & 5 & 0.05 \\
\hline & $60-80$ & 3 & 0.05 \\
\hline & $>80$ & 1 & 0.05 \\
\hline \multirow[t]{7}{*}{ Relief, R (m) } & $<150$ & 1 & 0.12 \\
\hline & $150-450$ & 3 & 0.12 \\
\hline & $450-750$ & 5 & 0.12 \\
\hline & $750-1100$ & 6 & 0.12 \\
\hline & $1100-1450$ & 7 & 0.12 \\
\hline & $1450-1700$ & 8 & 0.12 \\
\hline & $>1700$ & 9 & 0.12 \\
\hline
\end{tabular}

${ }^{a}$ Ranks of each factor (expert judgment)

${ }^{\mathrm{b}}$ Weight of the factors (AHP method). step was the springs' catchment area delineation (Bonac$\mathrm{ci}, 1987)$. The catchment area of each spring is calculated by the simple water-balance equation $\mathrm{CA}=\mathrm{Q} / \mathrm{PI}$ (Bonacci et al., 2006; Pezeshkpour, 1991; Karimi et al., 2001) where CA is the catchment area of the spring $\left(\mathrm{km}^{2}\right), Q$ is the total annual volume of water discharging from the spring $\left(\mathrm{Mm}^{3}\right.$ $\left.\left.\mathrm{y}^{-1}\right)\right], P$ is the annual precipitation $\left(\mathrm{mm} \mathrm{y}^{-1}\right)$ and $\mathrm{I}(\mathrm{mm})$ is the recharge coefficient. Determination of recharge coefficient is very difficult. It depends on many factors such as the presence or absence of sinkholes and dolines, joints and fractures, the thickness and granulation of soil cover, the slope of beds and topography, amount, type, time and space distribution of precipitation, temperature, and vegetation cover. The borderlines of the catchment areas were determined by using the proposed steps by Ashjari and Raeisi (2006).

\section{Results}

\section{Remote sensing (RS) and GIS}

Remote-sensing and GIS techniques were used to obtain the qualitative map of karstification in the study areas. The surface karstification index values were extracted by using

$$
\begin{aligned}
\mathrm{KD} & =\left(\mathrm{W} \sum \mathrm{R}_{\mathrm{K}}\right)_{\mathrm{Th}}+\left(\mathrm{W} \sum \mathrm{R}_{\mathrm{K}}\right)_{\mathrm{FB}}+\left(\mathrm{W} \sum \mathrm{R}_{\mathrm{K}}\right)_{\mathrm{FD}}+\left(\mathrm{W} \sum \mathrm{R}_{\mathrm{K}}\right)_{\mathrm{P}} \\
& +\left(\mathrm{W} \sum \mathrm{R}_{\mathrm{K}}\right)_{\mathrm{T}}+\left(\mathrm{W} \sum \mathrm{R}_{\mathrm{K}}\right)_{\mathrm{SAVI}}+\left(\mathrm{W} \sum \mathrm{R}_{\mathrm{K}}\right)_{\mathrm{S}}+\left(\mathrm{W} \sum \mathrm{R}_{\mathrm{K}}\right)_{\mathrm{R}}
\end{aligned}
$$

Where KD was karstification value, $\mathrm{W}$ was the weighting value of each factor, and $R_{K}$ assigned ranks to ranges of factors, including the thickness of carbonate formations Th, distance from faults FB, fracture density FD, precipitation $\mathrm{P}$, temperature $\mathrm{T}$, vegetation index $\mathrm{SAVI}$, slope $\mathrm{S}$, and relief $\mathrm{R}$. Each aquifer, from the karstification aspect, was classified into three classes from low, medium, and high. The index-weighting factors were done by using a combination of expert knowledge and database hierarchical analysis.

Karst development is carried out in seven karst aquifers (A1-A7) (Fig 6). In Figure 6, the positions of aquifers on the anticlines are also shown. $A_{1}, A_{2}, A_{3}, A_{4}, A_{5}, A_{6}$, and $\mathrm{A}_{7}$ aquifers are the catchment areas of $\mathrm{Sp}_{1}, \mathrm{Sp}_{2}, \mathrm{Sp}_{4}, \mathrm{Sp}_{7}$, $\mathrm{Sp}_{11}, \mathrm{Sp}_{19}$, and $\mathrm{Sp}_{21}$ springs, respectively. The final results of the estimated surface karstification index are presented in Table 4 and Figure 6 . The aquifers $A_{1}$ and $A_{2}$ have the lowest rates of karstification whereas the aquifers $A_{6}$ and $A$ show high rates of karstification. Other aquifers are distributed between these two groups.

The values of effective factors on karst development at the aquifers are presented in Table 5. The orders and effects of the factors on the karstification are dissimilar among the aquifers.

The highest value belongs to precipitation. Unless the aquifer rocks are crushed by a fault or the aquifer is located in lower elevation (i.e. less than 1500 meters). The catchment area of $A_{3}$ and $A_{4}$ are located at lower elevations relative to the others. Consequently, they receive the lowest precipitation. $A_{7}$ and $A_{4}$ are crushed by faults, which mainly control the karst development of the area. The thickness of aquifers is one of the lowest ranking factors in the condition that the catchment area is limited merely to the Asmari-Jahrum Formations. For instance, the catchment area of $A_{3}$ and $A_{4}$ extend to the Sarvak Formation, which is thicker than Asmari-Jahrum. 

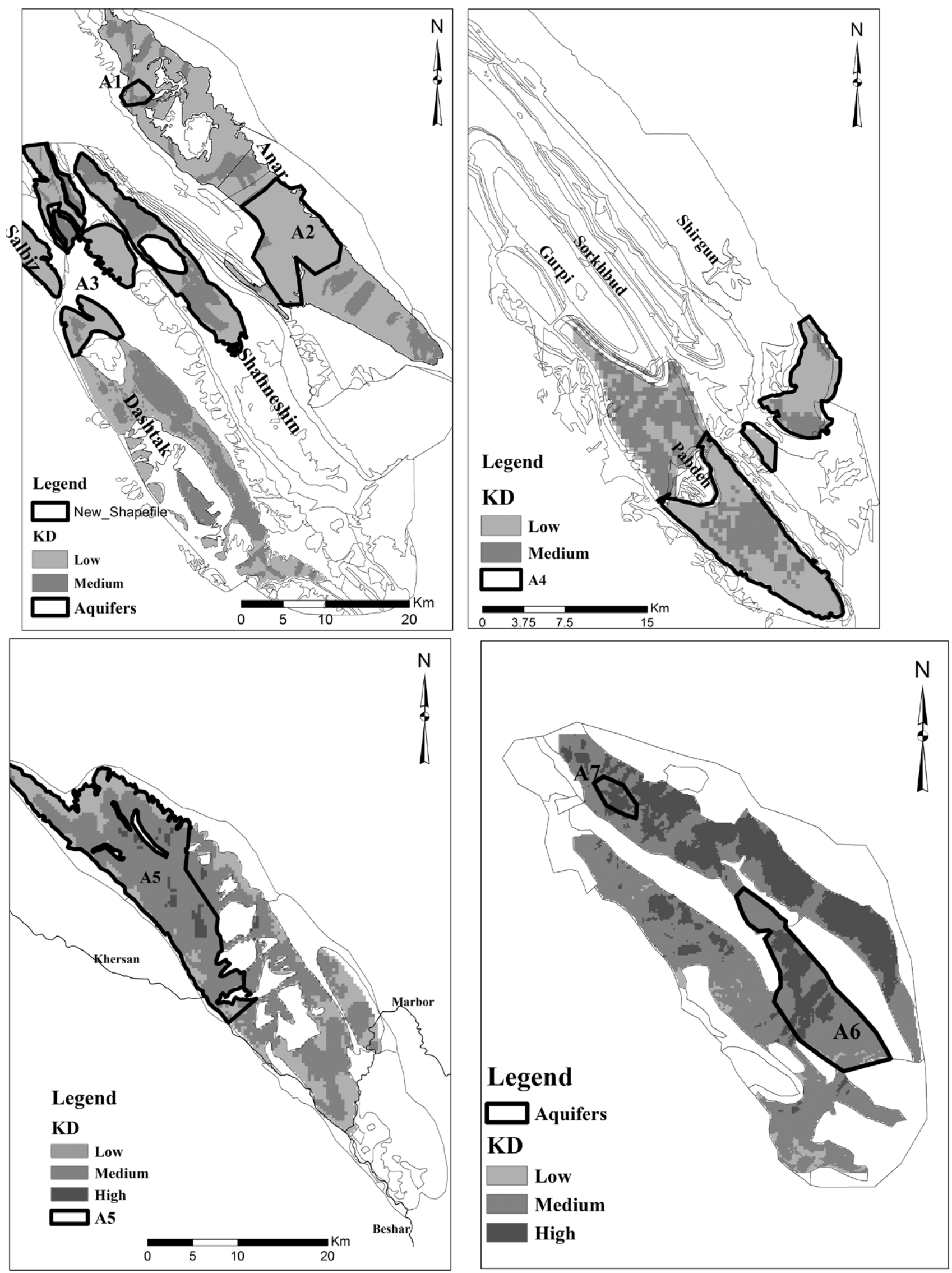

Figure 6. Karst Development at aquifers: $A) A_{1}, A_{2}$, and $A_{3}$ aquifers; $\left.B\right) A_{4}$ aquifer; C) $A_{5}$ aquifer; D) $A_{6}$ and $A_{7}$ aquifers. 
Table 4. Descriptive classification and statistical parameters of karst development (KD) in the study areas.

\begin{tabular}{|c|c|c|c|c|c|c|c|c|}
\hline Parameters & $\begin{array}{c}\text { Statistical } \\
\text { Description }\end{array}$ & $A_{1}$ & $A_{2}$ & $\mathrm{~A}_{3}$ & $\mathrm{~A}_{4}$ & $A_{5}$ & $A_{6}$ & $A_{7}$ \\
\hline \multirow[t]{3}{*}{ Percent area of karst development, KD } & Low & 75 & 84 & 68.5 & 69.8 & 57.49 & 2 & 0 \\
\hline & Medium & 25 & 16 & 31.5 & 30.2 & 40.11 & 68 & 49 \\
\hline & High & 0 & 0 & 0 & 0 & 2.4 & 30 & 51 \\
\hline \multirow{3}{*}{$\begin{array}{l}\text { Statistical parameters of karst development, } \\
\text { KD }\end{array}$} & Min & 2.01 & 2.31 & 1.84 & 1.72 & 1.63 & 3.79 & 5.14 \\
\hline & Max & 2.54 & 5.46 & 5.96 & 5.46 & 7.34 & 7.18 & 6.48 \\
\hline & Average & 3.76 & 3.88 & 3.9 & 3.6 & 4.49 & 5.48 & 5.99 \\
\hline
\end{tabular}

Table 5. Values of the effective factors on karst development at aquifers.

\begin{tabular}{|c|c|c|c|c|c|c|c|c|}
\hline ID & $\begin{array}{l}\text { Thickness of } \\
\text { Carbonate } \\
\text { Formations, Tha } \\
\text { (m) }\end{array}$ & $\begin{array}{c}\text { Precipitation, } \\
\text { Pb } \\
(\mathrm{mm} / \mathrm{y})\end{array}$ & $\begin{array}{c}\text { Distance } \\
\text { from Faults, } \\
\text { FB }^{b} \\
\text { (m) }\end{array}$ & $\begin{array}{l}\text { Fracture } \\
\text { Density, } \\
\text { FD }^{\mathrm{b}} \\
\text { (\%) }\end{array}$ & $\begin{array}{c}\text { Temperature, } \\
\mathrm{T}^{\mathrm{b}} \\
\left({ }^{\circ} \mathrm{C}\right)\end{array}$ & $\begin{array}{c}\text { Soil Adjusted } \\
\text { Vegetation Index, } \\
\text { SAVIb } \\
(\%)\end{array}$ & $\begin{array}{c}\text { Slope, } \\
\text { S }^{b} \\
(\%)\end{array}$ & $\begin{array}{c}\text { Relief, } \\
\text { R }^{\mathbf{b}} \\
\text { (m) }\end{array}$ \\
\hline$A_{1}$ & 28 & 86 & 76.51 & 59.32 & 28 & 7.34 & 42.9 & 12 \\
\hline$A_{2}$ & 28 & 98.73 & 40.33 & 70.92 & 32.5 & 2.1 & 42.2 & 19.7 \\
\hline $\mathrm{A}_{3}$ & 75.78 & 41.95 & 69.1 & 64.4 & 21.64 & 18.1 & 36 & 27.9 \\
\hline $\mathrm{A}_{4}$ & 51.9 & 35.28 & 132.94 & 58.2 & 14.25 & 0.02 & 39 & 20.75 \\
\hline$A_{5}$ & 28 & 805.31 & 48.87 & 87.6 & 36.1 & 18 & 38 & 53.1 \\
\hline$A_{6}$ & 112 & 117 & 100.1 & 47 & 35.1 & 18 & 38.9 & 68 \\
\hline $\mathrm{A}_{7}$ & 112 & 117 & 177.3 & 73.2 & 30 & 18.3 & 30.1 & 43.3 \\
\hline
\end{tabular}

The SAVI, slope, and temperature are among the lowest ranking factors. As expected, due to the dominance of the bare carbonate rocks in the Zagros region, the SAVI has received the lowest credit in all cases. The slope controls the recharge rate of the area, but the Asmari-Jahrum Formations are characterized by fractured aquifers. Therefore, the recharge role of the slope is weak. The precipitation and temperature are regarded as climatologic factors, but their effects on the karstification are dissimilar because the temperature variation rates are very low relative to the precipitation.

Relief and local base level, plays an unclear role in the karstification. If the aquifer is located near to the High Zagros Zone, the role of relief is important. Anticlines of this zone are pushed intensively together, and elevation variations are vast. The aquifers of the Simply Folded Zone are characterized by the broad amplitude of folding and a lower rate of elevation variations.

The results show that the karstification values of the aquifers of the same anticline are not equal or follow the same order. For instance, the $A_{6}$ and $A_{7}$ are located in the Delisib anticline, but the precipitation is more important in the $A_{6}$ than $A_{7}$. In fact, several faults cross the $A_{7}$ impact the precipitation priority, whereas the main faults are absent in the $A_{6}$.

\section{Springs Hydrograph Analyses}

Shokri et al. (2016) suspected to the equality of the surface karstification and internal karstification and suggested that they might be completely independent. Therefore, to understand the aquifer karstification value, the spring hydrographs are used to extract the karstification value based on the recession coefficients, the ratio of the quick flows to base flows, the ratio of dynamic storages to the catchment areas, and drying time of springs.

Hydrograph recession curve analysis is a technique commonly used to determine flow characteristics and karst development (Bonacci, 1993; Brodie and Hostetler, 2009; Kresic and Bonacci, 2010). The Maillet method (Maillet, 1905) for defining a hydrograph recession curve and determine spring flow characteristics is used, so hydrographs for springs were prepared.

Based on Kullman (2000), Malík (2007), and Malík and Vojtková (2012), a description of the recession of springs indicates that catchment areas of all springs are aquifers with irregularly developed fissure networks, with a majority of open macro-fissures, and with the possible presence of karst conduits of limited extent. In extreme cases, short-term turbulent flow might occur in this type of rock environment. Table 6 gives recession curve data, calculations related to dynamic storage, and drying time of springs. 
Table 6. Recession curve data, calculations related to dynamic storage and drying time of springs.

\begin{tabular}{|c|c|c|c|c|c|c|c|c|c|c|c|c|}
\hline \multirow[b]{2}{*}{ Spring } & \multicolumn{3}{|c|}{$\begin{array}{l}\text { Recession Coefficient } \\
\left(\mathrm{d}^{-1}\right) \\
\end{array}$} & \multicolumn{3}{|c|}{$\begin{array}{l}\text { Time } \\
\text { (d) }\end{array}$} & \multirow{2}{*}{$\begin{array}{c}\text { Discharge } \\
\text { Ratio } \\
\text { (Q/B) }\end{array}$} & \multicolumn{3}{|c|}{$\begin{array}{c}\text { Dynamic } \\
\text { Storage } \\
\left(\mathrm{Mm}^{3}\right)\end{array}$} & \multirow{2}{*}{$\begin{array}{c}\mathrm{V}_{0} / \mathrm{CA} \\
\left(\mathbf{M m}^{3} / \mathbf{k m}^{2}\right) \\
\end{array}$} & \multirow{2}{*}{$\begin{array}{c}\text { Drying Time of Springs } \\
\text { (d) }\end{array}$} \\
\hline & $\alpha_{1}$ & $\alpha_{2}$ & $\alpha_{3}$ & $t_{1}$ & $t_{2}$ & $t_{3}$ & & $v_{0}$ & $\mathbf{V}^{*}$ & $\mathbf{V}$ & & \\
\hline $\mathrm{Sp}_{1}$ & 0.047 & 0.008 & $\cdots$ & 20 & 15 & $\cdots$ & 1.5 & 2.43 & 0.68 & 1.75 & 0.32 & 770 \\
\hline $\mathrm{Sp}_{2}$ & 0.0062 & 0.0058 & $\cdots$ & 91 & 93 & $\cdots$ & 2.4 & 22.06 & 7.34 & 14.72 & 0.24 & 1200 \\
\hline $\mathrm{Sp}_{4}$ & 0.02 & 0.009 & 0.002 & 31 & 33 & 78 & 1 & 97 & 61.57 & 35.43 & 0.4 & 3445 \\
\hline $\mathrm{Sp}_{7}$ & 0.02 & 0.005 & $\cdots$ & 36 & 20 & $\cdots$ & 0.2 & 43.79 & 25.92 & 17.87 & 0.33 & 1400 \\
\hline$S p_{11}$ & 0.011 & 0.0025 & $\cdots$ & 45 & 60 & $\cdots$ & 0.35 & 40 & 28.5 & 11.5 & 0.46 & 2800 \\
\hline $\mathrm{Sp}_{19}$ & 0.01 & 0.003 & $\cdots$ & 96 & 70 & $\cdots$ & 0.25 & 35.48 & 16.58 & 18.9 & 1.31 & 2300 \\
\hline $\mathrm{Sp}_{21}$ & 0.007 & 0.017 & $\cdots$ & 106 & 31 & $\cdots$ & 1.5 & 5.02 & 0.46 & 4.56 & 2.79 & 400 \\
\hline \multicolumn{13}{|c|}{ 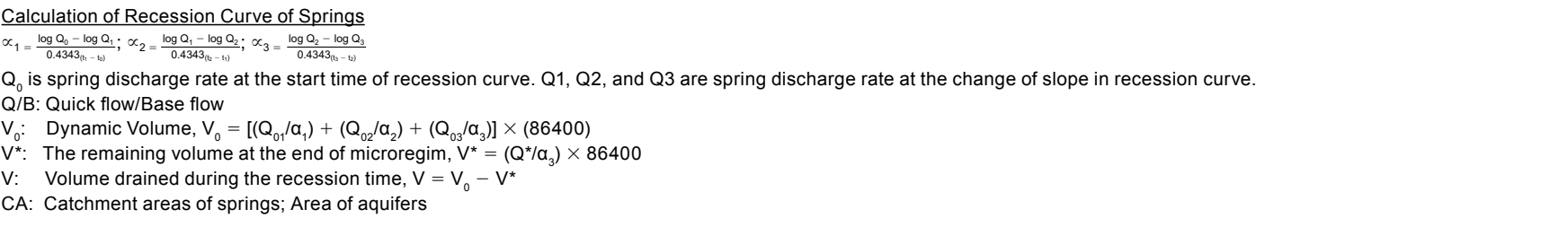 } \\
\hline
\end{tabular}

The first discharge recession coefficients of the springs are more than the second recession coefficients $\left(\alpha_{1}>\alpha_{2}\right)$ except the spring of $S p_{21}$ in the catchment area of $A_{7}$ where $\alpha_{1}$ is less than $\alpha_{2}$ due to recharge from snow melting that perturbs the recessional processes. The values of $\alpha_{1}$ vary from 0.0062 in $\mathrm{Sp}_{2}$ to 0.047 in $S p_{1}$ while the minimum and maximum values of the $\alpha_{2}$ are 0.0025 in $\mathrm{Sp}_{11}$ and 0.017 in $\mathrm{Sp}_{1}$. The ratio of recession coefficients $\left(\alpha_{1}: \alpha_{2}\right)$ changes from 0.4 in $\mathrm{Sp}_{21}$ to $5.9 \mathrm{in} \mathrm{Sp}_{1}$. The results show that the springs of the same anticlines may have highly different values of the recession parameters. For examples, $\mathrm{Sp}_{19}$ and $\mathrm{Sp}_{21}$ are emerging from the Delisib anticline, but the values of $\alpha_{1}, \alpha_{2}$, and $\alpha_{1}: \alpha_{2}$ for $S p_{19}$ are $0.01,0.003$, and 3.33 and values for $S p_{21}$ are $0.007,0.017$, and 0.41 . The high value of $\alpha_{1}$ can be representative of high internal karst development. The order of cases from high to low development is $\mathrm{Sp}_{1}, \mathrm{Sp}_{4}, \mathrm{Sp}_{7}, \mathrm{Sp}_{11}$, $\mathrm{Sp}_{19}, \mathrm{Sp}_{21}$, and $\mathrm{Sp}_{2}$. If the value of $\alpha_{2}$ is regarded as representative of karstification, the order of the springs will change from $\mathrm{Sp}_{21}, \mathrm{Sp}_{4}, \mathrm{Sp}_{1}, \mathrm{Sp}_{2}, \mathrm{Sp}_{7}, \mathrm{Sp}_{19}$, and $\mathrm{Sp}_{11}$. The values of $\alpha_{1}$ : $\alpha_{2}$ are considered in reverse order. The lowest value shows the highest development. In this condition, the springs' orders are $\mathrm{Sp}_{21}, \mathrm{Sp}_{2}, \mathrm{Sp}_{4}, \mathrm{Sp}_{19}, \mathrm{Sp}_{7}, \mathrm{Sp}_{11}, \mathrm{Sp}_{1}$. Therefore, the obtained results are non-unique in the recession coefficient analysis.

The next criterion considered as representative of the karstification of aquifers is the ratio of quick flow to base flow. Karst systems contain quick flow and slow flow components. These components are reflected in the springs' hydrographs. The highly developed aquifer has a very well-developed conduit system that stores and transfers the groundwater to the springs. Thus, the higher volume of quick flow/base flow can be considered as a fair criterion to karstification. So, the orders of springs from a high value of quick flow/base flow to a low value are $\mathrm{Sp}_{2}, \mathrm{Sp}_{1}, \mathrm{Sp}_{21}, \mathrm{Sp}_{4}$, $\mathrm{Sp}_{11}, \mathrm{Sp}_{19}$, and $\mathrm{Sp}_{7}$. The first three cases show the volume of the quick flow is more than base flow, whereas the other cases illustrate that the volume of the base flow is more than the volume of the quick flow.

The ratio of the dynamic volume of an aquifer to the catchment area is another criterion. The higher value of the ratio might be a representative of higher karst development. Regarding this criterion, the order of springs from the high value to the low value is $\mathrm{Sp}_{21}, \mathrm{Sp}_{19}, \mathrm{Sp}_{11}, \mathrm{Sp}_{4}, \mathrm{Sp}_{7}, \mathrm{Sp}_{1}$, and $\mathrm{Sp}_{2}$.

The last parameter which we address is the drying time of the spring. The well-developed conduit system of springs permits the groundwater flow from the farthest spot to the spring. Therefore the spring lasts for a long time in a drought climate. The order of springs from long lasting (3445 days) to short lasting (400 days) are $\mathrm{Sp}_{4}, \mathrm{Sp}_{11}, \mathrm{Sp}_{19}, \mathrm{Sp}_{7}, \mathrm{Sp}_{2}, \mathrm{Sp}_{1}$, and $\mathrm{Sp}_{21}$.

The springs of $\mathrm{Sp}_{1}$ and $\mathrm{Sp}_{2}$ are emerging from the Anar anticline and the springs of $\mathrm{Sp}_{19}$ and $\mathrm{Sp}_{21}$ are discharging the Delisib anticline. Although springs are located in the same anticline and in the same climate region, their obtained karstification orders are dissimilar. Therefore, it is impossible to compare results about one aquifer in one anticline to another aquifer in the same anticline.

\section{Discussion comparing surface and internal karstification}

Seven aquifers from five anticlines are located in different regions where their geologic structure and climatic characters are dissimilar in spite of their similarity of main lithology. Considering the priority of the aquifers in terms of karst development by different methods, they show absolutely non-unique orders that make it vexing to discriminate a highly karstified aquifer from other aquifers. For instance, the $\mathrm{Sp}_{21}$ shows the highest karstification order by using the GIS and 
remote sensing approach while the other methods assign it at least $4^{\text {th }}$ except the $\alpha_{2}$. The similarity of the order of the $\alpha_{2}$ and the GIS is not seen in other aquifers.

To find a probable relationship among these methods, linear and non-linear correlations of the absolute values of them were evaluated. The results show that in all methods, except between the obtained karstification values of the GIS-RS and dynamic volumes of the aquifers, there is no possible relationship among them. In fact, each method is referring to the specific character of a karstic aquifer. For instance, the $\alpha_{1}$ is mainly controlled by the conduit system development of an aquifer, which transfers the recharge water from the surface and epikarst to the spring. The $\alpha_{2}$ depends upon the matrix-medium interconnection of the aquifer and their exchange rates to the conduits delivering to the springs. The ratio of the $\alpha_{1}: \alpha_{2}$ shows the general proportion of the conduit system to the matrix. The drying time of an aquifer is related to the geometry of the aquifer and storativity of the matrix.

The GIS-RS method mainly regarded the surface parameters of an aquifer and climatic parameters that may enhance the karstification which may not apply for the interior part of it. The ratio of the dynamic volume to the catchment area of the aquifer is related to the surface infiltration rate and precipitation. These parameters are inherently similar to the parameters of the GIS-RS method that cause the high correlation between them (Fig 7).

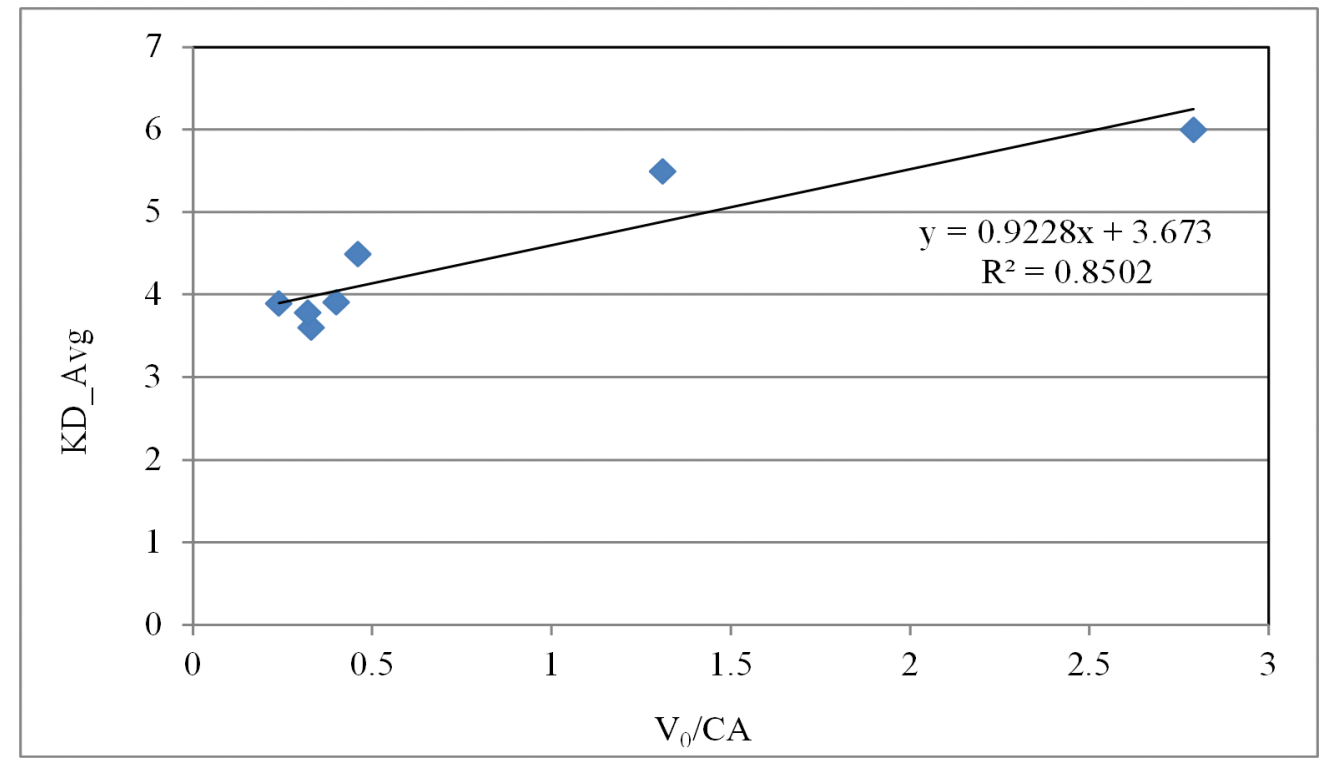

Figure 7. The relationship between the ratio of dynamic volume to catchment area versus KDavg.

\section{Conclusion}

The main question of this research was to determine if the surface and interior characteristics of karst aquifers were related in terms of karstification. GIS and remote-sensing methods aimed to assess the surface karst development in the study aquifers. The various methods include the $\alpha_{1}$ value of the discharge recession coefficient, $\alpha_{1}: \alpha_{2}$ ratio, the ratio of the quick flows to base flows, the ratio of dynamic storages to the catchment areas, and drying time of springs, were used to assess the interior characteristics of karst aquifers. The comparison of

GIS and remote-sensing studies with other methods for evaluating interior karst development indicated that these two processes are completely independent. Moreover, it is observed that the karstification values of the aquifers of the same anticline are not equal or follow the same order, suggesting that each method refers to the specific character of a karstic aquifer. The $\alpha_{1}$ and $\alpha_{2}$ values are mainly controlled by the conduit system and matrix of an aquifer, respectively. Thus, the ratio of the $\alpha_{1}: \alpha_{2}$ shows the general proportion of conduit system and matrix. The ratio of the quick flow to base flow is a reasonable criterion for karstification so that the higher volume of this ratio indicates higher karstification. The drying time of an aquifer is related to the geometry of the aquifer and storage capacity of the matrix. The most similarity between GIS-RS methods and other methods is its relation to the ratio of dynamic storages to the catchment areas. In fact, the ratio of the dynamic volume to the catchment area of the aquifer is related to the surface infiltration rate and precipitation.

In addition, mapping the degree of karst development in aquifers, based on some effective factors such as thicknesses of soluble rock and tectonic setting, precipitation, vegetation density, temperature, relief, and slope revealed that the orders and effects of these factors on the karstification are not uniform among the aquifers. It should be noted that the GIS-RS method is a comprehensive approach to assess surface karst development on a regional scale. The ability to alter weights on local scales is the main advantage of the GIS-RS method.

\section{References}

Aghanabati, A., 2006, Geology of Iran: Tehran, Ministry of Industry and Mines, Geological Survey of Iran, (In Persian) 587 p.

Alavi, M., 2004, Regional stratigraphy of the Zagros Folds-Thrust Belt of Iran and its proforeland evolution: American Journal of Science, v. 304, p. 1-20. https://doi.org/10.2475/ajs.304.1.1.

Ashjari, J., 2007, Classification of Zagros karstic aquifers based on general direction of groundwater flow and physico-chemical properties:

[Ph.D. Dissertation]: Shiraz, Iran, University of Shiraz, Iran. 
Ashjari, J., Raeisi, E., 2006, Influences of anticlinal structure on regional flow, Zagros, Iran: Journal of Cave and Karst Studies, v. 68, n. 3, p. 118-129.

Barany Kevei, I., 2007, Rules of climate, soils and vegetation development of karstsystem. - Time in Karst, Postojna, Slovenia: Short Scientific Papers. p. 1-4.

Bonacci, O., 1987, Karst Hydrology. Springer Verlag, Berlin, Germany. https://doi.org/10.1007/978-3-642-83165-2.

Bonacci, O., 1993, Karst springs hydrographs as indicators of karst aquifers: Hydrological Sciences Journal, v. 38 no. 1-2, p. 51-62. https://doi. org/10.1080/02626669309492639.

Bonacci, O., Jukic, D., and Ljubenkov, I., 2006, Definition of catchment area in karst: case of the rivers Krčić and Krka, Croatia: Hydrological Sciences Journal, v, 51, no. 4, p. 682-699, https://doi.org/10.1623/hysj.51.4.682.

Brodie, R.S., and Hostetler, S., 2009, A review of techniques for analyzing baseflow from stream hydrographs, Where Waters Meet, Auckland, New Zealand, New Zealand Hydrological Society (NZHS)..

CBRWA, 2012, Ministry of energy. Iranian water resource management: Chaharmahal and Bakhtiari Water Authority, http://www.cbrw.ir.

Chitsazan, M., Karimi Vardanjani, H., Karimi, H., an Charchi, A., 2015, A comparison between karst development in two main zones of Iran: case study-Keyno anticline (Zagros Range) and Shotori anticline (Central Iran): Arabian Journal of Geosciences, v.8, no. 12, p. 10833-10844. https://doi.org/10.1007/s12517-015-1961-x.

Dashti Barmaki, M., Rezaei, M., Ashjari, J., 2016, Recognition of karst hydrology and water resources interaction in Kazerun karstic zones, South of Iran: Arabian Journal of Geosciences. v. 9, no. 54, https://doi.org/10.1007/s12517-015-2092-0.

Ekmekci, M., and Tezcan, L., 2011, Management of karst aquifers under climate change: Implications for sustainable use: Baba, A., et al. (eds.), Climate Change and its Effects on Water Resources, NATO Science for Peace and Security Series C: Environmental Security 3.

Ford, D., and Williams, P., 2007, Karst Hydrogeology and Geomorphology: Chichester, U.K., John Wiley and Sons, Ltd, 562 p. https://doi. org/10.1002/9781118684986.

FRWA, 2012, Ministry of energy. Iranian water resource management: Fars Regional Water Authority, www.frrw.ir/

Huete, A.R., 1988, A soil adjusted vegetation index (SAVI): Remote Sensing of the Environment, v. 25, p. 295-309. https://doi.org/10.1016/00344257(88)90106-X.

Jamali, M., Moghimi, E., and Jafarpour, Z., 2015, Geomorphology of karst features of Shiraz City and Arjan Plain and development limitations: International Journal of Environmental, Chemical, Ecological, Geological and Geophysical Engineering, v. 9, no. 1, p. 25-31.

Kalantari, N., Keshavarzi, M.R., Hamidzadeh, F., and Sahebdel, M., 2010, Characteristics of heterogeneous Shimbar Karstic Systems in Southwest Iran: Advances in Research in Karst Media, Part of the Environmental Earth Sciences book series (EESCI), p. 69-74. https://doi. org/10.1007/978-3-642-12486-0_11.

Karami, G.H., Bagheri, B., and Rahimi, F., 2016, Determining the groundwater potential recharge zone and karst springs catchment area: Saldoran region, western Iran: Hydrogeology Journal, v. 24, no. 8, p. 1981-1992. https://doi.org/10.1007/s10040-016-1458-z,

Karimi, H., Raeisi, E., and Bakalowicz, M., 2005, Characterizing the main karst aquifers of the Alvand basin, northwest of Zagros, Iran, by a hydrogeochemical approach: Hydrogeology Journal, v. 13, no. 5-6, p. 787-799. https://doi.org/10.1007/s10040-004-0350-4.

Karimi, H.; Raeisi, E. and Zare, M., 2001, Determination of catchment area of aquifer bearing Tangab dam site using water balance method, in Proceedings of the Second National Conference on Engineering Geology and the Environment, Tehran, 16-18 Oct. 2001, v.2, p. 773-755.

Kresic, N., and Bonacci, O., 2010, Spring discharge hydrograph, in Kresic, N. and Stevanovich, Z., eds., Groundwater Hydrology of Springs: Engineering, Theory, Management, and Sustainability: Burlington, Mass., Butterworth-Heineman, p. 129-163.

Kullman, E., 2000, Nové metodické prístupy k riešeniu ochrany a ochranných pásiem zdrojov podzemných vôd v horninových prostrediach s krasovo-puklinovou priepustnost'ou (New methods in groundwater protection and delineation of protection zones in fissure-karst rock environment; in Slovak). Podzemná voda, no. 6/2, p. 31-41.

KWPA, 2012, Ministry of energy. Iranian water resource management: Khuzestan Water and Power Authority, http://www.kwpa.ir.

Lowe, D.J, 1992, The origin of limestone caverns: an inception horizon hypothesis, [Ph.D. Dissertation]: Manchester, U.K., Manchester Metropolitan University, $511 \mathrm{p}$.

Shokri, M., Ashjari, J., and Karami G., 2016, Surface and subsurface karstification of aquifers in arid regions: the case study of Cheshme-Ali Spring, NE Iran: Journal of Cave and Karst Studies, v. 78, no. 1, p. 25-35. https://doi.org/10.4311/2014ES0020.

Maillet, E., 1905, Essais d'hydraulique souterraine et fluviale. Hermann, Paris.

Malík, P., 2007, Assessment of regional karstification degree and groundwater sensitivity to pollution using hydrograph analysis in the Velka Fatra Mts., Slovakia: Water resources and environmental problems in karst: Environmental Geology, v. 51, p. 707-711. https://doi.org/10.1007/ s00254-006-0384-0.

Malík, P., and Vojtková, S., 2012, Use of recession-curve analysis for estimation of karstification degree and its application in assessing overflow/ underflow conditions in closely-spaced karstic springs: Environmental Earth Science, v. 65, p. 2245-2257. https://doi.org/10.1007/s12665-0121596-0.

Palmer, A.N., 2000, Hydrogeologic control of cave patterns: Speleogenesis: Evolution of Karst Aquifers, p. 77-90.

Panda, S.S., Ames, D.P., and Panigrahi, S., 2010, Application of vegetation indices for agricultural crop yield prediction using neural network techniques: Remote Sensing, v. 2, p. 673-696. https://doi.org/10.3390/rs2030673.

Pezeshkpour, P., 1991, Hydrogeological and hydrochemical evaluation of Kuh-e Gar and Barm-Firooz springs [M.S. Thesis]: Shiraz, Shiraz University, $282 \mathrm{p}$.

Raeisi, E., 2002, Carbonate karst caves in Iran Evolution of karst: From prekarst to Cessation, Ljubljana-Postojna, p. 339-344.

Raeisi, E., and Kowsar, N., 1997, Development of Shahpour Cave, southern Iran: Cave and Karst Science, v. 24, no. 1, p. $27-34$.

Raeisi, E., and Stevanovic, Z., 2010, Case Study: Springs of the Zagros mountain range (Iran and Iraq), in Kresic, N. and Stevanovic, Z., eds., Groundwater Hydrology of Springs, Elsevier, p. 498-515.

Saaty, T. L., 1980, The Analytic Hierarchy Process: New York, McGraw-Hill.

Seif, A. and Ebrahimi, B., 2014, Using GIS to evaluate degree of karstification according to some important factors in carbonate rocks in Iran: Carbonates Evaporites. v. 29, p. 107-126. https://doi.org/10.1007/s13146-014-0189-2.

Shabab Boroujeni, B., 2011, Determination of effective factors on permeability in karstic dams in west of Zagros [M.Sc. Thesis]: Tehran, Iran, Tehran University.

M. Shokri., Ashjari, J., and Karami, G., 2016, Surface and subsurface karstification of aquifers in arid regions: the case study of Cheshme-Ali Spring, NE Iran: Journal of Cave and Karst Studies, v. 78, no. 1, p. 25-35. DOI: 10.4311/2014ES0020. 
Stöcklin, J., 1968, Structural history and tectonics map of Iran: a review: American Association of Petroleum Geologists Bulletin, v. 52, no. 7, p. 1229-1258.

Stöcklin, J., 1974, Possible ancient continental margins in Iran, in Burk, C.A. and Drake, C.L. eds., The Geology of Continental Margins: New York, Springer-Verlag, p. 873-887. https://doi.org/10.1007/978-3-662-01141-6_64.

White, W.B., 1988, Geomorphology and Hydrology of Karst Terrains: New York, Oxford University Press, 464 p. 